\title{
Disjecta membra: Hacia una iconografía del cuerpo desmembrado
}

\author{
Disjecta membra: Towards an Iconography of the Dismembered Body
}

María Isabel Rojas ${ }^{a}$

\begin{abstract}
:
The article is an iconographic essay on the motif of the dismembered body. Due to the ubiquitous presence of images of dismembered bodies in the Mexican media, the author analyses the meanings this motif has conveyed, in order to understand the way images of dismemberment operate to produce an emotional reaction in the viewer. Influenced by the methods of the science of the image in German Scholarship (Bildwissenschaft), the article advances the application of an iconographical method to analyse images of violence in different cultural contexts.
\end{abstract}

Keywords: Dismemberment, iconography, Bildwissenchaft, visual studies, violence.

\section{Resumen:}

El artículo es un ensayo iconográfico sobre el motivo del cuerpo desmembrado. Dada la ubicuidad de imágenes de cuerpos desmembrados en la prensa en México, el autor analiza los significados que este motivo puede expresar, con el objetivo de comprender el modo en que las imágenes de desmembramiento operan para producir una reacción emocional en el espectador. Influenciado por los métodos de la llamada 'ciencia de las imágenes' de la tradición alemana (Bildwissenschaft), el artículo aborda el potencial de la aplicación de un método iconográfico al análisis de imágenes de violencia en diferentes contextos culturales.

Palabras clave: Desmembramiento, iconografía, Bildwissenschaft, estudios visuales, violencia.

\section{Introduction}

The notion of the fragment is aesthetically linked to the idea of modernity. The fragment has been used to refer to the experience of the transitory and the fleeting nature of modern social life as described in the 19th century by Charles Baudelaire (Baudelaire, 1863/2010; Frisby, 1985: 6-7). The fragment, according to Linda Nochlin, also reflects the aspiration of the French Revolution to destroy every vestige of repressive traditions of the past and use their pieces in revolutionary ways (1994:8). Nevertheless, the trope of fragmentation is not exclusive of modernity, and it has been frequently related to one of the most ancient fears of human beings, which is the awareness of their contingency. For this reason, the motif of the fragmented body has been a common topic, not only in modern and contemporary arts and literature (Nochlin, 1994; Pingeot, 1990) but also during many other periods.

In the specific case of Mexico, the topic is particularly relevant because of a now-ubiquitous practice of the drug cartels, consisting in placing dismembered bodies in public spots together with written messages on cardboard or banners, which are popularly known as narcomensajes or narcomantas (Maihold, 2011; Mendoza Rockwell, 2016). This brutal strategy of communication and intimidation is now part of the daily life in a country where people are more and more used to violent images and who have integrated such motifs to their collective visual memory. Concerned with the social effects of the dissemination of such images, and unsettled by their apparent effectiveness; I propose in his paper an introductory exploration of the iconography of the dismembered body as a way to interrogate a sample of images of dismemberment to examine the way they operate and convey meaning, and to describe the emotional responses that they activate in the viewers. My analysis will be focused on the differences between them, in relationship with their cultural contexts.

\section{Methodology}

In the course of the last thirty years, the discipline of art history has been radically transformed to respond to the functions of the image in the digital era. Starting with the so-called 'iconic turn', new theoretical and methodological approaches have been developed to examine the many ways by which images work and produce meaning

a Universidad Autónoma delEstado de Hidalgo-Instituto de Artes, https://orcid.org/0000-0002-3414-9626.Email: maria_rojas@uaeh.edu.mx 
(Moxey, 2008). A crucial author in this transformation was the German historian of culture Aby Warburg, who conceived Art history as an expanded discipline, which studies all kinds of images and not only those considered as art. Warburg established an academic tradition that in German scholarship has derived in a true science of images or Bildwissenschaft (Diers, Girst, \& von Moltke, 1995; Krieger, 1999; Rampley, 2012).

Drawing from this tradition, I examine the transformation of the motif of dismemberment following the notion of pathos formel, conceptualized by Warburg as a figurative formula that is charged with strong emotional energy and which produces a powerful response in the viewer. According to Warburg, the visual memory of humankind is shaped by such expressive formulas that have been used since ancient times, and which constantly renew their power of expressiveness by acquiring new layers of meaning in every cultural context where they appear (Forster, 1996: 19). The exploration of the transformations that one visual motif has undergone has the potential of making visible the accumulated strata of meanings in collective imagery, thus the pathos formeln work as mnemonic repositories (Forster, 1996: 21).

The indissoluble intertwining of an emotional charge and an iconographic formula that the notion of pathos formel entails makes impossible to distinguish between form and content (Agamben, 1999: 89). This way, the visual motif can convey latent irrational meanings that might not be noticed at first, but that contribute to the impact of the image in the response of the viewer. With this idea in mind, I will examine some examples taken from a variety of contexts in which the motif of the dismembered body is present. With this description, I intend to shed light on the way these images function and on the meanings they can convey, thus, as KurtForster has stated, "a work of art can unexpectedly bring to light an origin, something long forgotten" (1996: 16). The repertoire of images associated with the motif of dismemberment that I examine in this paper comes from a variety of cultural backgrounds. The discussion starts with two examples of dismemberment in ritual contexts, taken from the stories told in Greek and Aztec mythologies. It later continues with some pictures collected from Christian iconography, and finally closes with the analysis of two artworks with political overtones. Without pretending to make an exhausting analysis of this wide topic, I focus on paradigmatic examples as a way of starting a discussion that will be further elaborated in the next stages of this research project.

\section{Dismemberment and Sacrifice}

In the Mexican cultural tradition, the motif of the dismembered goddess Coyolxauhqui has central relevance. The circular stone relief with the image of the dead body of Coyolxauhqui is one of the key pieces at the Museo del Templo Mayor in Mexico City (Figure 1). The goddess is depicted with the limbs separated from the torso, and the head also severed and thrown back, filling the circular shape of the monolith and representing the position in which Coyolxauqui's corpse lay on the ground after falling from the mount Coatépec. The mythical story of the dismemberment of Coyolxauqui is described at the Códice Florentino (Sahagún, 1577/1989: 300-302). Sahagún refers that Coyolxauhqui's death was the result of a myth ic battle foughtby the moon goddess and her 400 brothers (the stars or centzonhuitznahuac) against her brother, the solar deity Huitzilopochtli. The story seems to mix historical elements of the encounter of the Aztecs with a dissident clan, with religious aspects of a cosmic battle between the diurnal and nocturnal powers (González de Lesur, 1968).

The stone relief of Coyolxauqui was originally placed at the foot of the stairs of the pyramid dedicated to Huitzilopochti at the Templo Mayor, acting as a physical mark in that sacred space (Matos Moctezuma, 1990; Cué, Carrizosa \& Valentín, 2010). During the battle, Huitzilopochtii beheaded Coyolxauqui and threw her body down the hill. The fall represented her defeat, while the dismembement of her body signalled her destruction. Therefore, the relief worked as an imprint of Huitzilopochtli's victory. In symbolic terms, the dismemberment of Coyolxauhqui denotes a transfer of power to her brother, thus the rise of one means the fall of the other (Scolieri, 2004: 93). Such transfer of power should be continuously updated through the ritual, by which the primordial sacrifice was renovated through new human sacrifices performed on the top of the pyramid. The bodies of the victims were thrown down the stairs to fall exactly on the site where the petrified body of the defeated goddess lay. This way, Coyolxauhqui's relief was simultaneously a monument and a stage that commemorated the power of the vanquisher at the very place where new victims would be killed, often before the eyes of guests from other nations to intimidate them.

The relief of Coyolxauqui displayed its presence and acted as an unburied corpse that updated the myth and reinforced the power discourse. The military and political power of the Aztecs were elevated to cosmic level by their symbolical assimilation with the solar divinity: Justas every sunrise the victorious sun conquered the night and the darkness, the Aztecs would inevitably triumph against their enemies. Employing this symbolic device, mundane military actions were en dowed of a universal character and 
presented as ineluctable and eternal. The myth installed the political order of the winners and legitimated it. We find reminiscences of this political strategy in some of the narcomantas used by the Mexican drug cartels, which vindicate vicious murders as acts of an alleged "divine justice" (Mendoza Rockwell, 2016: 26-27). This similarity is an evidence of the intertwining of political power with forms of religious power. According to M.B. ter Borg, power often appears in complex constellations in which religious power intermingles with political, economic, sexual, or other forms of power (2011: 205). The use of the motif of dismembermentin these two cases that I compare reveals how political discourses reinforce their effectiveness when they include a religious component that refers to superhuman realities and meanings. Since religions help humans to cope with mortality, political discourses connected with references to death become even stronger. This dimension of the exercise of power has been explored in connection with the notion of necropolitics, addressed by Giorgio Agamben (1997) and Achille Mbembe (2003).

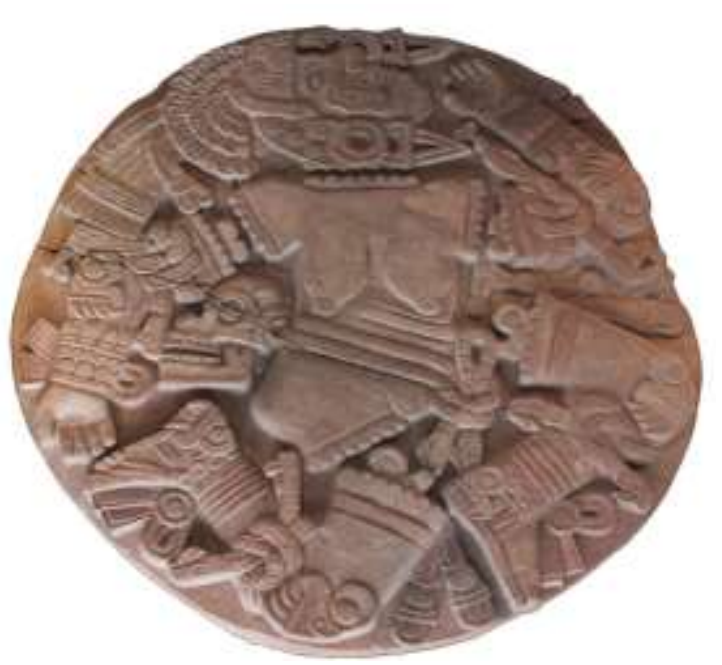

Figure 1. Coyolxauqui, Aztec culture, late Post-classic period. Reliefon andesite, $3.25 \mathrm{~m}$. Museo del Templo Mayor, Mexico.

Other examples of the use of the motif of dismemberment are found in several pieces of pottery from ancient Greece (See Weaver, 2009). On one of the faces of an Attic kylix conserved at the Kimbell museum in Texas (figure 2), we see two maenads holding the head and the torso of Pentheus, king of Thebes, in a scene that depicts his sparagmos or ritual dismemberment. The sparagmos of Pentheus is described in the ancient tragedy The Bacchae, written by the Athenian playwright Euripides. In the play, Pentheus dies at the hands of a group of maenads in a god-maddened state, led by Agave, the victim's mother, who mistakes his son for a wild beast and rips him to shreds with her bare hands. Pentheus' sacrifice is orchestrated by the god Dionysus, who was affronted by Pentheus when he denied his divine character and prohibited his cult (Euripides, 405 B.C.E./1944). At the Kimbell kylix, Pentheus' torso appears with the bowels hanging from beneath, and held by two women, one on each side, ready to tear him apart. The victim directs the head upward, with the eyes rolled back, approaching his imminent death. One maenad to the far left upholds one of his legs, while Agave handles his clothes and look up to the sky unaware of her victim's identity. A satyr, with a perplex gesture on his face, completes the scene on the right side. On the back of the vase, we see Dionysus, sitting on a throne and holding a kantharos in his hand, while enjoying the flute music that another satyr plays in presence of other three maenads.

The dreadful death of Pentheus brings the tragedy of the destruction of the unity of the human body to its peak by giving the mother the role of the perpetrator of the barbaric act. Nevertheless, there is a reason for such brutality. A variety of passages at the Bacchae highlight the refusal of Pentheus to recognize the divinity of Dionysus as the cause of his death. When Pentheus disregarded the divine nature of the god, he was also repudiating the primary aspects of human nature, namely its irrational character. That is the reason why his life ends due to an irrational act, and it is no coincidence either that the final state of his body is to be fragmented, which would be the state of the human being if a part of his nature were eliminated. The decoration of this kylix - normally used to drink during the symposia - seems to function as a reminder of the fatal destiny awaiting to those who fail to acknowledge their irrational nature through song, dance, and intoxication. In this sense, the sparagmos of Pentheus is obviously related to the notion of the loss of the self, either by effect of the influence of the irrational, or by self-fragmentation (Henrichs, 1984:207).

The plausibility that gruelling rituals like Pentheus' sparagmos were a real practice has been diversely interpreted. E.R. Dodds for instance, affirms that Dionysiac rituals might have been a way of norming and controlling mass hysteria, by creating an organised ritual, which was also a reminiscence of a primitive religious cult anterior to Orphism (1940: 159-169). On the contrary, J.N. Brenner reads Dionysiac ritual as a symbolic derivation of a more moderate practice, which might have been exaggerated in the myth as an extreme action (1984: 28). Whatever the relation ritual-myth was, the practice and representation of sparagmos reflect the ritualising of a disturbing aspect of human nature that confers to images of dismemberment their strong emotive energy: the horror of the disintegration of the unity of a human being. 


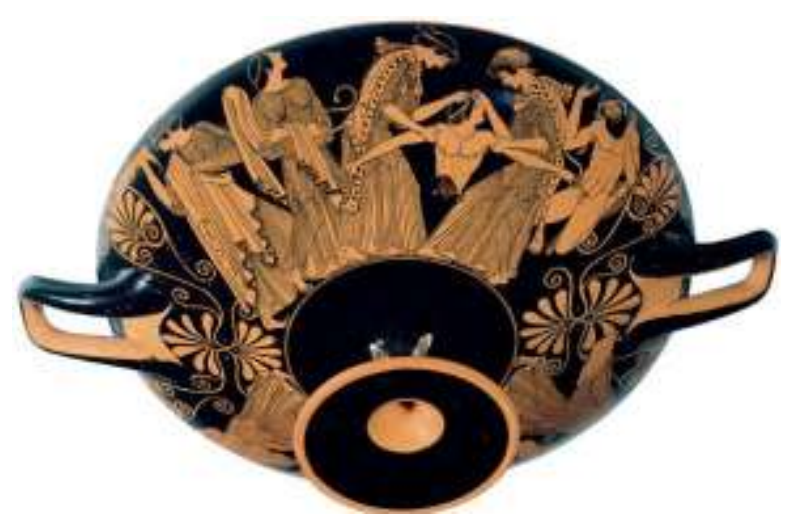

Figure 2. Douris (vase painter), red-figure cup showing the death of Pentehus (exterior), ca. 480 B.C., Terracotta, $12.7 \mathrm{~cm}$. (height) $29.2 \mathrm{~cm}$ (diameter). Kimbell Art Museum, Texas.

\section{Dismemberment and Martyrdom}

When exploring the subject of the dismemberment of the human body in Western culture, it is almost impossible not to refer to the influence of Christian iconography on the topic. Many martyrs, like St. James Intercisus or St. Pelagius of Cordova, found the death by the dismemberment of their bodies. St. James, for instance, was a Persian martyrfrom the $5^{\text {th }}$ century, who was hacked into thirty pieces by the orders of a local tyrant. The punishment was determined because of the political menace that Christians meant to the Persian king, and because of the treason of James, who was favoured by the tyrants' father and denied his faith, only to take it back later (Devos, 1953; Carruthers, 2011).

In some of the representations of the martyrdom of St. James, his body appears at the centre, cut in pieces, as an object that testifies the cruelty of his executioners (figure 3). According to the Golden Legend, St. James stoically suffered the torture, pronouncing different prayers each time that a part of his body was taken, and filling every action of his torturers with pious meaning (Jacobus, 1260/2012: 729-732). This hopeful attitude reveals the conviction that the terrible violence that he was suffering would be neutralised by the eternal life of his soul.

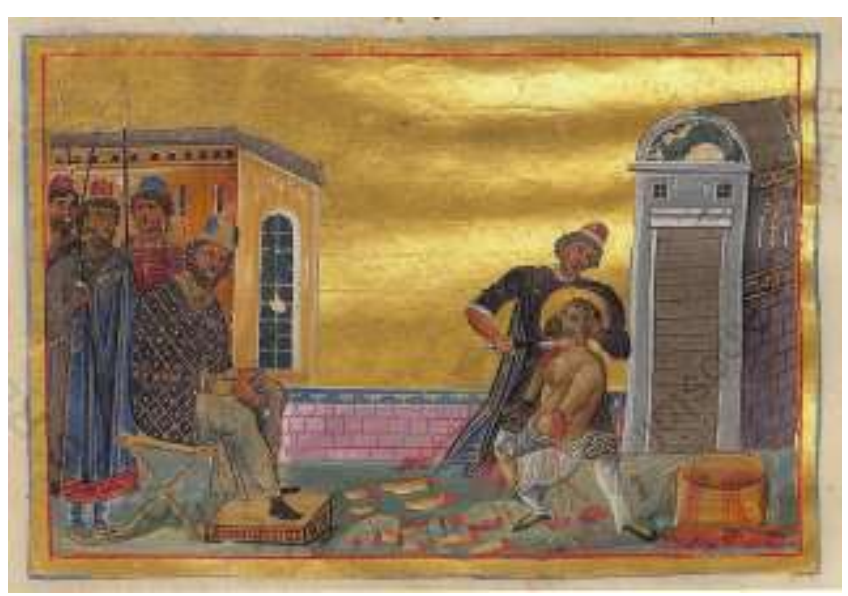

Figure 3. Martyrdom of St. James'Intercisus', ca. 1000 AD, Manuscript. Menologion of Basil II, p. 209, Vatican Library.

Harsh scenes of martyrdom cover the walls of many Christian churches. Among them, the decoration of Santo Stefano Rotondo, in Rome, is one of the most interesting ones. The chapel of the College of Jesuits is decorated with bloody pictures that would probably serve the purpose of preparing the future missionaries for the atrocities they will face as part of their work of evangelization. ${ }^{1}$ We can imagine the young novice monks, praying every day in front of the brutal images painted on the walls of the chapel, which announced their destiny. These paintings exhibited the spectacle of their future death, a death that they must be quite aware of. The graphic depiction of the ripped flesh, the interior of the body, opened to the exterior and showing its most intimate secrets, the dislocation of its unity and the consequent vanishing of its identity, all of these details were not simple representations; they imbued the images of a presence that addressed directly to the deepest fears of the viewers and allowed them to face the psychological impact of an overwhelming and terrifying reality.

These violent pictures were only bearable because of the promise of its reversibility. The counterpart of the images of dismembered martyrs can be found in some depictions of the last judgement, especially in those from the Byzantine tradition (figure 4). In such images, it was usual to depict fish and beasts regurgitating the limbs of the human bodies they had swallowed, so they could be reassembled at the end of time. The hope of Christian believers that the unity of their being was secured, no matter what happened to their bodies, was the greatest promise that the resuscitated body of Christ announced (Bynum, 1991: 11-13; 1995: 117-155). This way, the depictions of dismemberment in the context of Christian

1 Images of the chapel are available at: shorturl.at/cMNZ7 and shorturl.at/juSTW 
iconography are shocking, butat the same time reassuring because they counteract mundane misfortune with the certainty that human pain and death could be surpassed by divine justice and transcendence. In this sense, images of dismemberment work also in a political way, by highlighting the cruelty of non-Christians and securing the invulnerability of Christians believers.

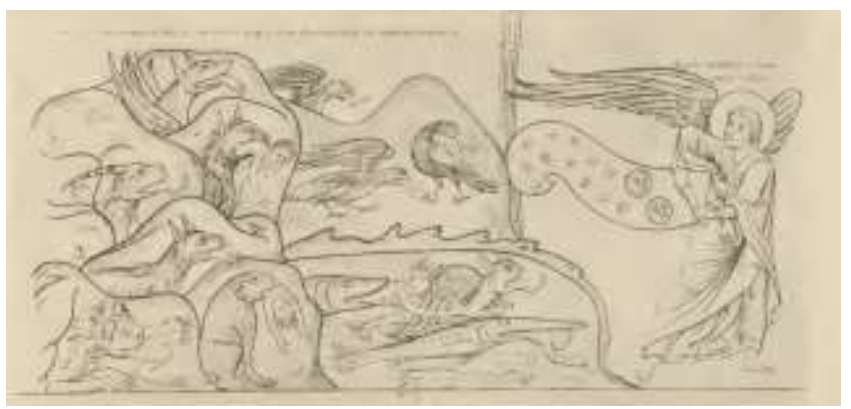

Figure 4. The Last Judgement, manuscript Hortus Deliciarum (reconstruction), ca. 1176-1196, fol. 251r, pl. 141.

\section{Dismemberment: Art and politics}

A different point of view is offered by the painting "El Desmembrado" (The Dismembered) by José Clemente Orozco (figure 5), originally shown at the exhibition "Los Teules," presented in 1947 at El Colegio Nacional. Orozco makes use of the motif of the dismembered body to evoke the violence related to the Spanish conquest of Mexico. In the painting, the bruised corpse of a dismembered Aztec warrior with the limbs displaced seems to float in a void of blood. Edmundo O'Gorman has suggested that the painting contains no propaganda or political thesis, thus it does not take sides; rather it 'shows' a raw and brutally sincere presentation of reality (as cited in González Mello, 2001:277). The ravaged body of the Mexica warrior is the face of the violence, exercised and suffered evenly by Aztecs and Spaniards. Its reverse side is shown in another painting of the same series called 'Sacrificio Humano' (Human Sacrifice), in which the body of a Spanish conquistador is pierced with a knife and sacrificed by a group of indigenous people. In contrast with the relief of Coyolxauqui that I described below, the body of El Desmembrado is more dynamic. He seems to be floating, as if his dismemberment were a perpetual process. Coyolxauqui suggests unity because of the disc whereon she lies, her limbs are harmonically placed, implying immobility. In contrast, the composition made by Orozco placed the severed body in an impossible position, with the torso dislocated and suspended in a void surrounded by blood. This body is an allegory of a fragmented nation, dismembered, ou traged and in conflict; the violent process of Conquest left behind only a handful of fragments, which cannot be reassembled in a coherent unity.

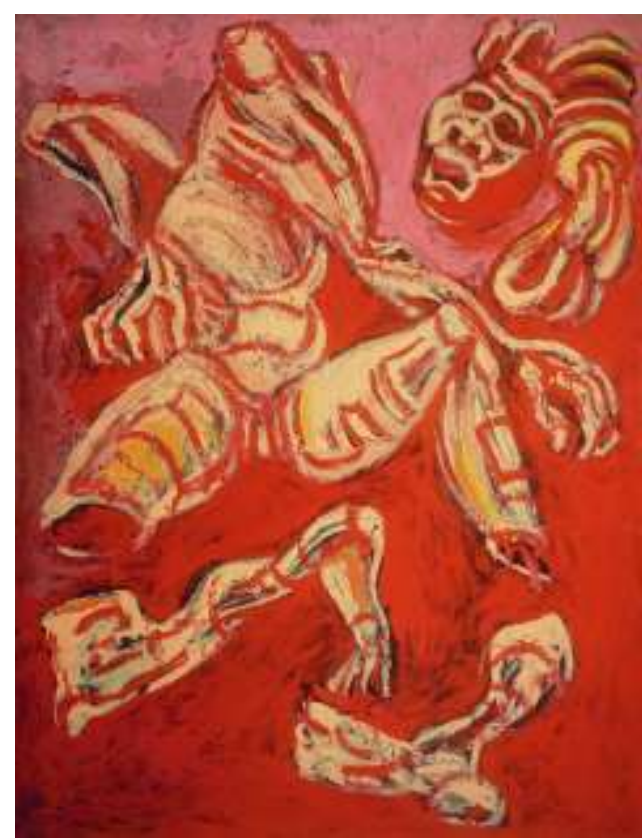

Figure 5. José Clemente Orozco, El desmembrado, 1947, oil on masonite. Museo Nacional de Arte, Mexico.

The representation of dismemberment as an allegory of political defeat is also addressed in one of the frescoes at the ceiling of the Sala di Constantino at the Vatican Palace. The Sicilian painter Tommaso Laureti decorated the vaulted ceiling between 1582 and 1585 with a painting entitled The Triumph of the Cross (figure 6). In the picture, we observe a sumptuous hall with marble columns and arches. At the centre of the room, a big bronze cru cifix with the figure of Christ rises on the top of a marble pedestal. Facing the crucifix, a broken antique statue of Mercury, representing the pagan idols, is lying on the floor. The crucifix is placed at the threshold of a corridor, preventing anyone from passing to the back rooms of the building. The Sala di Constantino was used for official receptions and ceremonies, and consequently had great symbolic relevance. It was named after the first Roman emperor who recognized the catholic religion, adopting the freedom of worship (Musei Vaticani, 2020). The sumptuous hall depicted in the ceiling evokes the palatial environment of the seat of Christianity to ennoble the glory of the triumph of Catholicism, which started with the rejection of Constantine of idolatry (Freiberg, 2009: 49-50).

In both examples described above, we see parallel uses of the motif of dismemberment in art to communicate opposite political messages. In Orozco, the emphasis is placed on the irreparable damage inflicted to the defeated, producing a sense of empathy. Conversely, at the Sala di Constantino, the suffering body of Christ rises victoriously over the falling body of the vanquished pagan idol. The 
broken sculpture does not inspire any sympathy and is depicted as a lifeless object.

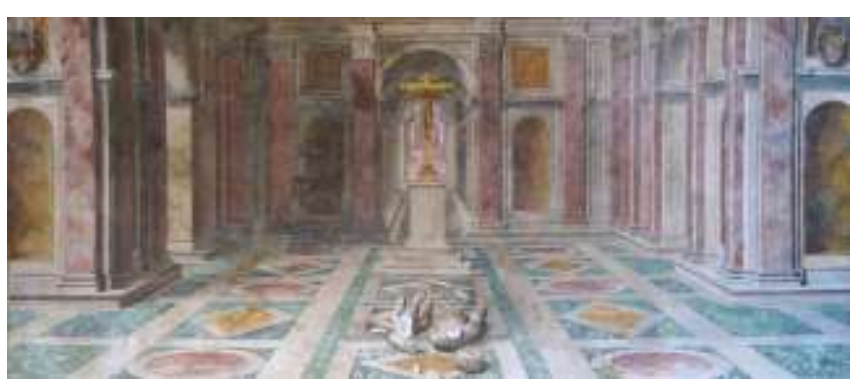

Figure 6. Tommaso Laureti, Triumph of The Cross, 1585, freso. Sala di Costantino, Vatican Palace.

\section{Transcultural Intersections}

The images described in the former sections are a few examples of the many ways in which the motif of dismemberment has been represented in different cultural contexts. The comparison shows that dismembermentis a form of extremely violent death that has been depicted to inspire deep feelings of awe and fear. The impact that an image of dismemberment can have is not solely related to the pain that this form of death can inflict, but mainly to a basic emotion of discomfort produced by observing the human body in pieces and the loss of its unity. In the story of Pentheus, Dionysus' rage is not only targeted to the Theban king, but also to his mother Agave. At the end of the play, Agave goes back to her home, holding the head of her son in her hands as a hunting trophy, unaware of her deeds. One of the climax moments of the play occurs when she realises what happened. Both in the myth of Coyolxauqui and the martyrdom of St. James, there are no explicit references to the pain they suffered. The horrific aspect of the story is the spectacle of their destruction and the realisation of the fragility and vulnerability of their bodies. In this sense, the image works as a mirror. When observing the fragmented body of someone else, the viewers experience their own vulnerability in a tangible way, and that is why these images are so powerful.

Conversely, the total annihilation of an opponent would be the core idea of the images of dismemberment used in political contexts. That is the sense of The Triumph of the Cross and also of the Coyolxauqui's relief. A final defeat is permanent and irrevocable when the opponents are eliminated, and there is no better proof of their obliteration than their human remains, spread on the ground and humiliated. In this sense, we observe the close linkage between religion, psychology and politics. A political message is stronger when accompanied by robust visual devices. The motif of dismemberment mobilises fear, but also a religious attitude of respect and surrender on the front of a power or force that is perceived as beyond human understanding. Nevertheless, there is always the hope of exceeding human vulnerability with the help of a god (St. James and the scenes of the Last Judgement) or, at least, by being the closest to the powerful god: the executor, rather than the victim. Ultimately, the only comfort that one can find in an image of violence is that it is inflicted to someone else rather than oneself. That is the idea at the core of Walter Burkert's (1983) and René Girard's (1977) interpretations of sacrifice as a tolerated, localized violence that helps to prevent widespread violence and social instability.

In the catalogue of the exhibition El cuerpo aludido: anatomías y construcciones, presented in 1999 at the Museo Nacional de Arte (México), José Luis Barrios describes three modalities of fragmentation: psychological, symbolic, and physical (1998). This article has shown that in the images of dismemberment many different aspects come in play, and that the extraordinary energy of the motif is the product of a combination of symbolic and psychological forces that intervene and reinforce each other. No matter if we speak of a religious image or one of political use, the images of dismemberment mobilise aspects related to human psychology, its physicality and its religious dimensions. The motif accumulates new layers of meaning and updates its power in every appearance. In images of dismemberment, we observe archaic elements, but also new ones, showing that some human reactions are similar, even if they occur in different spatial and temporal contexts.

\section{Conclusions}

In her book Cuerpos sin duelo, lleana Diéguez addresses the dichotomy absence/presence conceming the bodies of the desaparecidos (victims who were abducted and usually murdered in the context of a political conflict). Diéguez examines a variety of visual strategies used with political purposes to provoke fear, and distinguishes between the uses of the body in the context of art, in which the body is a representation, and the real corpses used to script discourses of power on them. Referring to the Colombian anthropologist Elsa Blair, Diéguez affirms that the staging of scenes of violence reaches its highest point when corpses are used as representational vehicles (2013:11-16), as in the example of the narcomantasthat I mentioned above. Without intending to deny the drama of the phenomenon of the narcomensajes, I would like to point out to one particularity that images of dismemberment share, either they are built with actual 
corpses or with artistic techniques like painting or sculpture.

When dealing with images of dismemberment, we observe that they have a particularity that makes them different from other images. From the perspective of the anthropology of images suggested by Hans Belting (2007; 2011), "the picture involves a representation which produces an impression of presence" (2016: 235). The 'iconic presence', as Belting calls it, refers to what is absentin the picture (whatis depicted), but that is still there as a presence. The iconic presence is a performing capacity of the visual artefact, which in the Christian tradition, behaved like a living body that wept and worked miracles.

For Belting, as well as for other scholars engaged in the analysis of the power of images, such as HorstBredekamp (2018) or David Freedberg (1989), factual presence and symbolic presence are not necessarily detached. The genesis of the image in ritual contexts, for instance in death masks, drew from the assumption that an image brings what is missing, back (Belting, 2007: 1-9). In a parallel way to spiritualist mediums who invite spirits to manifest through their bodies, images are the hosts of fears, affections, and all kind of basic human drives. The working hypothesis that I started to detail in this paper is that the motif of dismemberment, due to the topic it depicts, acts in the same manner as the religious images described by Belting, no matter if it is exhibited in a sacral or a secular context. The reverence and the fear produced by the sight of a fragmented corpse activates religious meanings, no matter if it is presented as a fresco in a Christian chapel, like in Santo Stefano Rotondo, or on a photograph at the front-page of a sensationalist newspaper.

There is, of course, much more to explore in matters of the viewers' response to the image. This paper is just a first glance to a complex topic that will be further elaborated in the future with the analysis of new examples of the motif of dismemberment taken from additional cultural contexts. This analysis will be limited neither to identify similarities between the images nor even to trace the possible interchanges orborrowings from one cultural context to the other. My approach has been rather focused on exploring the multiple meanings that images display when they are addressed as visual artefacts that embody, by means of forms and gestures, collective fears and complex psychological issues. I hope that in this paper I have set out the first steps to discuss the potential of an iconographic cross-cultural study of the images.

\section{Photo credits}

Figure 1. Stone relief of Coyolxauqui, Museo del Templo Mayor, Instituto Nacional de Antropología e Historia, México. https://www.templomayor.inah.gob.mx/images/salas/sala2/1.jpg

Figure 2. Red-Figure Cup Showing the Death of Pentheus and a Maenad, Kimbell Art Museum, Texas (AP 2000.02). https://www.kimbellart.org/collection/ap-200002

Figure 3. Miniature from the Menologion of Basil II, p. 209, Digital Vatican Library (Vat.gr.1613)

https://digi.vatlib.it/view/MSS_Vat.gr.1613/0207?sid=a7590df9b8aca2211 1c8359533716419\&zoomlevel=4

Figure 4. Miniature of the Last Judgement, Hortus Deliciarum of Herrad of Landsberg, f. 251r (305), Internet Archive (gri_33125010499123). https://archive.org/details/gri_33125010499123/page/n303/mode/2up

Figure 5. José Clemente Orozco, El Desmembrado, Museo Nacionalde Arte, México. http://munal.mx/munal/acervo.html

Figure 6. Tomma so Laureti, Trionfo della religione Cristiana (detail), Musei Vaticani, Sala di Costantino. http://www.museivaticani.va/content/museivaticani/it/collezioni/musei/stan ze-di-raffaello/sala-di-costantino/trionfo-della-religione-

cristiana.html\#\&gid=1 \&pid=1

\section{References}

[1] Agamben, G. (1997). Homo sacer. Paris: Seuil.

[2] Aga mben, G. (1999). Aby Warburg and the Nameless Science. In G. Aga mben, \& D. Heller-Roazen, Potentialities: Collected essays in philosophy (pp. 89-103). Stanford, Cal.: Stanford University Press.

[3] Barrios Lara, J. L. (1998). El cuerpo fragmentado. In J. Soler Frost, El cuerpo Aludido. Anatomías y construcciones (pp. 173-182). México: Patronato del Museo Nacionalde Arte, CONACULTA, INBA.

[4] Baudelaire, C. (2010). The painter of modern life and otheressays (J. Mayne, Trad.). London: Phaidon Press. (Original work published 1863)

[5] Belting, H. (2007). Likeness and presence: A history of the image before the era of art. Chicago: University of Chicago Press.

[6] Belting, H. (2011). An anthropology of images: Picture, medium, body. Princeton: Princeton University Press.

[7] Belting, H. (2016) Iconic Presence. Images in Religious Traditions. Material Religion, 12(2), 235-237.

[8] Bredekamp, H., (2018). Image acts: A systematic approach to visual agency (E. Clegg, Trad.). Berlin: De Gruyter.

[9] Bremmer, J. N. (1984). Greek maenadism reconsidered. Zeitschrift für Papyrologie und Epigraphik, 55, 267-286.

[10] Burkert, W. (1983). Homo necans: The anthropology of ancient Greek sacrificial ritual myth. Berkeley: University of California Press.

[11] Bynum, C. W. (1991). Fragmentation and redemption: Essays on gender and the human body in medieval religion. New York: Zone Books.

[12] Bynum,C. W. (1995). The Resurrection of the Body in Western Christianity, 200-1336. New York: Columbia University Press.

[13] Carruthers, L. (2011). A Persian Martyrin a Middle English Vernacular Exemplum: The Case of St James Intercisus. Medieval Sermon Studies, 55(1), 13-30. 
[14] Cué, L., Carrizosa, F., \& Valentín, N. (2010). El monolito de Coyolxauhqui: investigaciones recientes. Arqueología mexicana, 17(102), 42-47.

[15] Devos, P. (1953). Le dossier hagiographique de S. Jacques l'Intercis. I: La Passion grecque inédite (BHG. 772). Analecta Bollandiana 71, 157-210.https://doi.org/10.1484/J.ABOL.4.02358

[16] Diéguez, I. (2013) Cuerpos sin duelo: Iconografía y teatralidades del dolor. Córdoba, Argentina: Ediciones DocumentA/Escénicas.

[17] Diers, M., Girst, T., \& von Moltke, D. (1995). Warburg and the Warburgian tradition of cultural history. New German Critique, 65, 5973.

[18] Dodds, E. R. (1940). Maenadism in the Bacchae. Harvard Theological Review, 33(3), 155-176.

[19] Euripides (1944) Bacchae (E.R. Dodds, ed.). Oxford: Clarendon Press. (Original work published ca.405 B.C.E.)

[20] Forster, K. W., (1996). Aby Warburg: his study of ritual and art on two continents (D. Britt, Trans.). October, 77, 5-24.

[21] Freedberg, D. (1989). The power of images: Studies in the history and theory of response. Chicago: University of Chica go Press.

[22] Freiberg, J. (2009). Pope Gregory XIII, Jurist. Memoirs of the American Academy in Rome, 54, 41-60.

[23] Frisby, D. (1985) Fragments of Modernity: Theories of Modernity in the Work of Simmel, Kracauer andBenjamin. Cambridge: Polity Press.

[24] Girard, R. (1977). Violence and the sacred (P. Gregory, Trans.). Baltimore: Johns Hopkins University Press.

[25] González de Lesur, Y. (1968). El dios Huitzilopochtli en la peregrinación mexica: de Aztlán a Tula. In Anales del Instituto Nacional de Antropología e Historia, 19, 175-190.

[26] González Mello, R. (2001). La victoria impía.Edmundo O'Gorman y José Clemente Orozco. In R. Eder (Ed.), El Arte en Mexico: autores, temas, problemas (pp. 273-302). México: Fondo de Cultura Económica.

[27] Henrichs, A. (1984). Loss of Self, Suffering, Violence: The Modern View of Dionysus from Nietzsche to Girard. Harvard Studies in Classical Philology, 88, 205-240.

[28] Jacobus, de Voragine, (2012). The Golden Legend: Readings on the Saints (W.G. Ryan, Trans.). Princeton, N.J.: Princeton University Press. (Original work published ca. 1260)

[29] Krieger, P. (1999). Las posibilidades abiertas de Aby Warburg. In L. Enríquez Rubio (Ed.), (In) disciplinas: Estética e Historia del arte en el cruce de los discursos, XXII coloquio de Historia del Arte (pp. 261280). México: Universidad Nacional Autónoma de México.

[30] Maihold, G. (2011). Las comunicaciones criminales: el caso de las Narcomantas. In S. Aguayo, \& R. Benítez (Eds.), Atlas de la seguridad y la defensa de México 2012 (pp. 83-92). México: Colectivo de Análisis de la Seguridad con Democracia.

[31] Matos Moctezuma, E. (1990). Las seis Coyolxauhqui: variaciones sobre un mismo tema. Estudios de Cultura Náhuatl,21, 115-30.

[32] Mbembe, J. A., (2003). Necropolitics (L. Meintjes, Trans.). Public culture, 15(1), 11-40.

[32] Mendoza Rockwell, N. (2016). Narco-mantas o el confín de lo criminal. Acta poética, 37(2), 21-34.

[33] Moxey, K. (2008). Visual studies and the iconic turn. Journal of Visual culture, 7(2), 131-146.

[34] Musei Vaticani (2020, March) Sala di Constantino . http://www.museivaticani.va/content/museivaticani/it/collezioni/musei /stanze-di-raffaello/sala-di-costantino/stanza-di-costantino.html

[35] Nochlin, L. (1994). The body in pieces: The fragment as a metaphor of modernity. London: Thames and Hudson.
[36] Pingeot, A., dir. (1990). Le corps en morceaux. Paris: Musée d'OrsayEditions de la Réunion.

[37] Rampley, M. (2012). Bildwissenschaft: theories of the image in German-language scholarship (pp. 119-134). In Art History and Visual Studies in Europe. Leiden: Brill.

[38] Sahagún, B. (1989). Historia general de las cosas de Nueva España: Vol 1 (A. López Austin, \& J. García Quintanar,Eds.). México: CONACULTA. (Original work published 1577)

[39] Scolieri, P. (2004). Coyolxauhqui's impact: Aztec historiography and the falling body. Women \& Performance: A Journal of Feminist Theory, 14(1), 91-106.

[40] Ter Borg, M. B. (2011). Religion and Power. In P. Clarke (Ed.), The Oxford Handbook of the Sociology of Religion (pp. 194-209). Oxford: Oxford University Press.

[41] Weaver, B. (2009). Euripides' Bacchae and classicaltypologies of pentheus' sparagmos. 510-406 BC. Bulletin of the Institute of Classical Studies, 52, 15-43. 